\title{
A Evolução do Uso de Elementos Químicos por Sistemas Biológicos ${ }^{\dagger}$
}

\author{
J, J.R. FRA ÚSTO DA SILVA *
}

\section{INTRODUÇÃO}

A análise de dilercutes tipos dc urganismos c, em especial, das diferenças cncontradas entre organtsmos anaeróbicos (mais primitivos) e as espécies aeróbicas actuais, mostra que houve mudanças substanciais na sua composição e na forma colno os elementos se disıribuem nas células e são nclas unilizados.

Para compreender essas mudanças lıverá que ter em consideração as alteraçōes registadas na composiçào da superf́cic da Terra to na da atmosfera desde ha corca de 4 biliôes de anos. Inicialmente redulora, contendo provavelmente gases como $\mathrm{H}_{3}, \mathrm{CII}_{4}, \mathrm{NH}_{3}, \mathrm{H}_{3} \mathrm{~S}$ e $\mathrm{H}_{2} \mathrm{Sc}$, hem como outros mais oxidados $\mathrm{CO}, \mathrm{CO}_{2} \mathrm{CN}_{2}-$, além de $\mathrm{H}_{2} \mathrm{O}$, a atmostera atingiu a sua conposiça acIual liá menos de $1 / 2$ biliẫo de anos. Ao mesmo tempo, a superficic terrestre passou a ser constituida essencialmcintc por óxidos quando antes tinha certamente uma percentagen subsiancial de sultureios. O mar, por scu lado, teră evoluído progressivamente de um porencial redox baixo em torno dos -0.5 a 0.0 volts, até aos 0.8 volis actuais. Iniciamcnte bastante ácido, devido ao teor elevado de ácido clorídrico, o seu pl] foi subindo lentamente devido à dissoluçãu de óxidos e carbonatos. atingindo um valor já na zona alcalina, cerca dc 8, por tamponizaçâo com lidrugenocarbonato.

Nestas condiçổes, algumas espécies quimicas inicialmente não disponiveis por estarem na lorma de sulfuretos muito pouco solúveis, por exemplo os jócs $\mathrm{Hg}^{2+}, \mathrm{Ph}_{2}^{2+}, \mathrm{Cu}^{+}+\mathrm{c}$ $\mathrm{Cu}^{-}, \mathrm{Cd}^{2+}$, e cul nicnor grau o läu Zn12+, torinaram-5c progressivamente mais đisponíveis devido à oxidaçāo do sulfureto a sulfato, enquanto que outras, inicialmente disponiveis, se tornaram quase indisponívcis, por excmplo o ferro que passou de $\mathrm{Fe}^{2+}$ a Fe ${ }^{i+}$, cujo hidróxido tem um produto de solubilidade bastante haixo. Com a subida do pll tambéts o $\mathrm{Ni}^{2+}$ c." Co ${ }^{2+}$, já de si poltco abundantes. passaram por uma lase de menor disponibilidade, «nquanto o vanádio c' a molibdénio, os elcmentos de transiçāo mais abundantes na água do mar, sc mantiveram sempre disponiveis na forma catiónica, $\mathrm{Mo}^{3+} \mathrm{e}$ $V^{3+}$. ou na forma aniónica. quer como $\mathrm{MoS}_{4}^{2}$ e VS, quer como $\mathrm{MoO}_{4}^{2-}$ L $\mathrm{VO}_{3}$. Tambem o izo $\mathrm{Mn}_{\mathrm{n}}+\mathrm{l}^{4} \mathrm{i}$ pouco afectado, pois o produto de solubilidade do seu sulfureto não é sulicientemente baixo.

Naturalmente, us iōen alcalinos e alcalino-terrosos não sofreram altcração. «mbora a conccentração do cálcio scja regulada (tamponizada) pelo carbonato. De notar ainda que o ferro poderia formar c levetá ter formado inicialmente, con alguma facilidade, agregados terro-cuxolre. $\mathrm{Ft}^{2+} / \mathrm{Fe}^{3+} / \mathrm{S}^{2}-$, $170 \mathrm{~s}$ quais parte do ferro pode ser substituido por $\mathrm{Ni}+\mathrm{C}^{2}$ parte do sulfureto pode ser substituído por selcinicto, Se2-. Os agregados Mos $_{4}^{2-} \mathrm{VS}_{3}$ podem, igualumente. ligar-se aos agregados ferro-enxofre, originando as nitrogenases.

Os restantes elementos nuctálicos são pouco abundantes ou pouco disponiveis (por formarem sulfurctus muito pouco soluveis), e entre os elcututos não metálicos o lostato nằ) sofreu alteraçẳo, bem cottio us halogéneos, prosentes naturalmugte como halogenctos no estado $X^{-}$(só mais tardc. por ação de peroxidases. puderam ser oxidados. por exemplo a hipodarito, $\mathrm{ClO}^{-}$. ou combinados covalentementc cn moléculas orgâricash. Os suliuretos e selunictos foram progressivamente oxidados a sulfatos e seleniatos, como já referido.

O silício forma um óxido insulúvel. a sílica. $\mathrm{SiO}_{2}$, e uma grande variedade de silicalos. mas alguns desies são parcialmente sulúvis $\mathrm{cm}$ meio ácido. pelo quL este elemento usteve sempre disponivel como ácido silíciCo. S] $(\mathrm{OH})_{4}$.

(Estc relato suctinto e simplificado pốc en evidencia as analugias yuc existem enı te a evolução descrila c a chamada "marcha geral" de análise química de soluçōes. baseada principalmente no uso dos iōes sullureto, hidróxido e carbonato. Conlotme se verá, as analog̣ias são profundas também com a quimica e funços dos difurentes elementus cm sistemas biologicos, cuja compreensão exige os conbecimentos adquiridos nas disciplinas de quimica-anatitica teórica. Não deixa dé ser irónicu verilicar quc estas disciplinas tendem a ter un tratameltu) de deslavor, ou mesmo a sercon suprinidas dos cursos universitários de biologia. geol)gia e até de quinica ...).

A vida na Terra, gialquer gue tenla sido a sua origen - tema de que năo nos ocuparcmos - lerâ dic ter utilizado as "matérias-primas" disponiveis em cada época e uptimizado o seu uso. Cada espécie de orgamismo, representada por um detorminado código gencitico, é uma experiência bem sucedita de adequaçào an ambientc, que é necussariamente posta em causa quando cost ambiente a alterado de forma não transitória ou quando o códign genérico solre qualquer agressão que o modifica. Isto é. especiaçāo biológica. código genélico (AI)N) e ambiente estão necessariamtente ligados.

Assim teremos que ver cm que medida as alterasōes anbientais duscritas tiveram ou 17 ăo repercussōes concretas e directas na evoluçăo das espécius. Isto é, teromos que respolnder a perguntas tais como: Qual a consequencia da progressiva oxigenução do ambicnte? Qual o cefeito da oxidação fo sulfureto? Qual o elèto da queda de disponibilidade do ferro? Qual o efeito do atmento do disponibilidade do zinco? Qual? eleito do aumento de disponibilidade do cobrt? Qual o efciu do aumctito de, pur exemplo, $\mathrm{Cd}^{2+}$, ou $\mathrm{Ph}^{2 *}$, ou $\mathrm{Hg}^{2+}$. ou $\mathrm{A}^{3+}$, edc. ssto é, de elemenuos não utilizados habitualmentc, ver Figura I, no ambicnte de uña cspécic bioligica delerminada? E podemos, tambért, perguntar como é que os organjomos vivos obtem os elt:mentos que necessitam nas quantidades adequadas, cumo eliminam us qué thes sầo prèudiciais, e que principios presidem à coordenaçã dos diferentes papćis dos elementos utilizados e ao aumento de complexi. dade dos seres vivos ao longo dos biliücs de anos de evolução, das hacrérias mais ancestrais até à espécic humana. 


\begin{tabular}{llllllllllllllllll}
1 & 2 & 3 & 4 & 5 & 6 & 7 & 8 & 9 & 10 & 11 & 12 & 13 & 14 & 15 & 16 & 17 & 18 \\
\hline
\end{tabular}

(H)

\begin{tabular}{|c|c|c|c|c|c|c|c|c|c|c|c|c|c|c|c|c|c|}
\hline Li & Be & & & & & & & & & & & 8 & (c) & (N) & (0) & \begin{tabular}{|l|} 
\\
\end{tabular} & $\mathrm{Ne}$ \\
\hline (No) & (Mg) & & & & & & & & & & & Al & $\mathrm{Si}$ & (9) & (s) & (c) & Ar \\
\hline (א) & (C) & $\mathrm{Sc}$ & $T_{t}$ & \begin{tabular}{|l|}
$v$ \\
\end{tabular} & $\mathrm{Ca}$ & {$\left[\overline{M_{n}}\right]$} & \begin{tabular}{|l|}
$\mathrm{Fa}$ \\
\end{tabular} & $\mathrm{Co}_{0}$ & Ni & $\mathrm{Cu}$ & $\mathrm{Zn}$ & Go & $\mathrm{Ge}$ & IAs! & $\mathrm{se}$ & Br & $K_{i}$ \\
\hline Rb & isn? & $Y$ & $\mathrm{Zr}$ & No & Mo & Te & Ru & Fh & Pd & $\mathrm{Ag}_{\mathrm{g}}$ & {$[\mathrm{Cd}$} & In & isn: & $\mathrm{Sb}$ & $\mathrm{Te}$ & 1 & $x_{e}$ \\
\hline$C_{s}$ & [Ba] & $\operatorname{Ln}$ & $\mathrm{H} f$ & $T a$ & $\mathrm{~W}$ & $\operatorname{Re}$ & Os & Ir & Pt & Au & $\mathrm{Hg}$ & TI & $\mathrm{Pb}$ & Bi & Po & At & $\mathrm{Rn}$ \\
\hline $\mathrm{Fr}_{\mathrm{r}}$ & $\mathrm{R} \theta$ & $\mathrm{Ac}$ & Th & $P_{g}$ & U & & & & & & & & & & & & \\
\hline
\end{tabular}

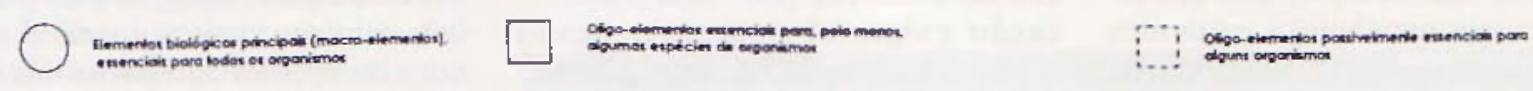

Fig. 1 - Quadro periódico evidencianda os elementos réqueridas por arģanismsus.

As resposias a estas e outras perguntas sāo essenciais para a compreensāo do lenónı̀no que chama. mos vida e para a reconsideração de algumas verdades adquiridas que. em nosso entender, nāo estăo a ser correctamente equacionadas, por exemplo a presumida indispensabilidade e supremacia do código genético. isto é. da mulćctula ADN, na exis. tência e evolução das espécies biológicas.

Apresentar algumas respostas. apontar implicaçōes a questionar 1eorias sāo os objectivos que nos propomos nesta conlerência, necessariamente superticial c escassa em pormenores dada a ıxtensāo do tema.

\section{O QUE PERMANECEU E O QUE MUDOU}

A selecçāo e incorporação no citoplasma das células primitivas de um enпjunto básico de elementos requeridos pelos organismos anacróbicos manteve-se essencialmente inalterada em todos os subsequentes estádios de evolação, mesmo quando a disponibilidade de alguns desses elementos mudou dramaticamente. Na Tabela 1 apresentam-se diversos tipos de reacçūes que se mantiveram

Tabela 1

Processos e percursos melabólicos mantidos ao longo da evoluçâo biológica

Processo qu pareurso melabólico

Exemplo (alamentos químic os envolvidos)

Sintese da DNA. RNA

Cicło dos d́cidos tncarboxilicos

Sintese de amino-úcidos

strilese de prateinas

Sinłese e degradaçao de poilssacánidos

Sintese de ácidos gordos

Incorporaçâa de azoto
Peacurso dos ácidos nuclèlcos, iMğ. 2n. Fers.

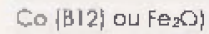

Introporaçăo de $\mathrm{CO}$, iposter armente úlilizodo paro o armazenamenta do energia - ciclo de Krebs (fe. Mgil)

Pradulos de glicćlise e do cicla de Kreas $+\mathrm{NH}_{3}$ i'Fel

Formileção inicict (fe) e inteiaçăo do sintese pela metionina |Fe. Col

Gicolise "Mgl

Oxidoçao/feduçao de carbonos - In [ilavina. Fe!

folmaçāo de $\mathrm{NH}_{3}$ [Mg. Fe. W. Mo] em bactèrios simbióticas

$\mathrm{H}_{2}$ camo redutor (Fe. Nill em anquebacterias [oncếrbibas] 
ao lango de 3.6 biliōes de anus de evolução. É fácil compreender que assim teria de ser para assegurar untra séric de polímcrus essenciais ácidos nucleicos (ADN. ARN), protcínas, lipidos, polissacáridos - que permanecem necessários nas formas de vida actuais. Como estas reacçōes ocorrem па ausência do oxigénio. o metabolismo lutracelular manteve-se redulor até loje e os requisitos dc clementos em quantidades controladas permanecom identicos. A consequência ólıvia á que a evolução dependeu largamente de adiçoss, usando as alıeraçôes ambientass, cm ve7 de implicar substituiçōes nos principais percursos metabólicos existentes no citoplasma celular dos organismos anaeróbicus, os quais são essencialmente conservadus ainda quuc com algumas adaptaçōes, A analogia aqui é com o desenvolvimento das cidades modernas, que se expandem adicionando novos bairros mas conservando o "cenıro" sem grandes al. icraçóes ..

Todavia a progressiva disponibilidade de outros elementos antes nà utilizados, como o cobrc, ou pouco utilizados, como o zinco. não podia deixar de ler implica. çöes. até porque estas espécics tên maior afinidade para os centros aos quais se ligam outros elementus já anles utilizados. pur exemploo lcrro, convém tor presentc aqui a order de estabilidade termodinàmica de Irbing-Williams para os complexus de iones bivalcnies: $\mathrm{M} \Pi<\mathrm{Fe}<\mathrm{Co}<\mathrm{Ni}<\mathrm{Cu}>\mathrm{Zn}$ ). Eтп геsu mo, tornou-se necessário proteger o citoplasma incorporando os novos elementus através de percursos cinćticos (cm que o metal thăo se dişo. cia lacilmente) e armazenando-os 'im organelas ou vesículas separadas daquele compartimento, nas quais as condiçôes predominantes são diferentes e mais semelhances ao ambiente cxiracelular. Assim, os novos percursos reaccionais imuito do mcabolismo secundário) decorre fora do citoplasma. Quanto aos elementos que sc tornaram escassus. como o ferro, e quc continuaram a ser esscincias, houve naluralmente quc descrvolver esquemas de captura mais solisticados, como por exemplo a sintesc de sequestrantes potenciais a enviar ao exterior das células isiderótoros, no caso do ferros. bem como dispositivos de armazenamento (por exemplo at lerritinas. e que desenvolver tambúm métodos de reciclagem para poupar tnergta.

Logicamente, a célula é um todo, pelo que as organelas e vesículas têm de comunicar com o citoplasma. do qual estầ separadas por mombranas, de forme a terem uma acçãu concertada. O mesmo aconlece com a célula como um todo em relaçào ao meio exterior. Essa comunicação exige, olvviamentu. hovos minsageiros químicos, antcs näo necessánios já que atdo se passava num Linjco compartimentu interno.

(t.m à parte recordemos que. desde inficio, alguns ións, designadamente o $\mathrm{Na}^{+}$, c o $\mathrm{Cl}^{-}$. tiveram que ser expelidos (bombeados) para lora das células (o que uxige energia...) de forma a evitar protrlemas de pressão osmórica dada a elevada concentração destes ióes na água do mar en que a vida sc desenvolveu. Também o $\mathrm{Ca}^{2}+$ teve que ser bumbeado para o cxterior em larga medida pois intemamente iria combiuar-se e bloqucar centros aniónicos. por exemplo carboxilatos. para os quais tem uma alinidade moderada.

Em contrapartida, para assegurar neutralidade interna tnotar que us políncirus orgânicos em causa tền carga negativa). K+ $\mathrm{CMg}^{-+}$foram acumulados no interior das células. Formaram-se. assim. gradientes dc concentração. com constquências importantes para a transmissào dc mensağens e jara a mincralizaçăo $\mathrm{c}^{\circ}$ mais iarde para a produçäo de encrgia).

$\Lambda$ questāo principal que c'stas altcrações suscitam é a da coexistûncia ao lungo do processo evolutivo de um metabolismo jrimário conservado no ciroplasma enquanto. simultaneamonte. se desenvolveu uma química diferentc nas organclas e vesículas, t posteriormente nos fluidos internos exira-celulares dos organismos mais desenvolvidos. Mas como altcraram as ctilulas os setts requisitus para responder às alturaçōes de disponibilidade de vários clementutos?

Una explicaçào possivel é que as alteraçoes ambientais induzem necessariamente tensōes e eventualmente danos nas células dos organis mos existentes, perfeitamente adaptados a outras condiçōes, sobrctudo em cerlas proteínas mais vulneráveis. A resposta do código gเnético sera. naturalnetnte. stibstiturir as proteimas afcctadas. o quc requer que $v$ DNA intconsitịule a transcriça dus guncs cortespondentes, para que passará mais verzes pela situaçâa de hélice simples, situação assa por seu lado tambin mais vulnorável a ataques de agcontes agressivos lais como $\mathrm{O}_{2}$. NO. $\mathrm{Zn}^{2+} \mathrm{CL}^{2+}$, levando à ocorrû́ncia de eventuais mutaçôes localizaclas. O resultado será o descnvolvjmento de novos gones e novas proteinas adaptadas às novas situaçồts. pois se assim năo suceder us organismos em causa deixam de ker viáveis a extinguem-sc rapidamente com o decorter do tempo. Deste modo o código gunético aumcnıou e altcrou-se. e os novos organismos tornarant-se mais complexos. Ainda que siuplista. esta explicaçäo ć coerente com v que é ubstrvado. A teoria que a evoluça se da simplesmente atra. vếs de nutaçôes alcalórias até que o sel sornatorio leve, por acasi, a um prganismo mais viável, suscita as maiures dúvidas pela sua flagrantc improbabilidade.

\section{AS RESPOSTAS DO CÓDIGO GENÉTICO}

Cunvém fazc aquí uma breve digressào sobrú o código gen nético e a forna como este responde às necessidades das células no que se rufere à rciciçăo. captura, distribuiçăo e controle dos difurentes elementos disponívcis no meto em que os organismos se encontram. $\hat{f}$ um tema muito pouco conhecido. mas que se torna indispensavol abordar aqui, ainda quc de forma muito superlicial, pois é verdadeiramente fulcral jara 0 chltuntimento da tstreita ligaçào entro 
a vida e o ambiente. Näo cntrarcmos em questōes básicas já perfeitamente esclarecidas, como sejam a natureza do cótigo (ADN) e a forma como ele st expressa (por cópia-transcrição e traduçāo ao nível dos ribosomas) levando à sintese de proteńnas (c de alguns lipos de ARNsi. Assim mesmo nāo deixaremos de salientar a imprecisão com quc alguns destes lactos passam para os mllanuais de ensino criando ideias lalsas e obscurecendo a compreensão. Como primeiro exemplo a própria molecula do ADN que só por si nada faz - sem a complexa maquinaria calular é tăo inerte como qualguer polímero vulgar. Por outro lado, só aparece na ultra-publicitada forma de teélice dupla nas bactérias: nos restanles organismos com cálulas mucleadas o ADN enrola-se em torno de um conjunto de proteínas, cntrc as quais as chamadas histonas, de forma a ficar confinado a un pequeno volume compativel corn as dimensoes do núcleo. Akin disso não é lido de fontra linear e contínua. Os genes (grupos do nucleótidos que especificam uma proteína ou um determinado ARN) ıèm, nas células nucleadas, espaços entre eles (introns) que não codificam nada c são climinados quando se forma a molćcula do ARN mensageiro a ser traduzicto).

(A analogia aqui é com o teclado de um piano em que os genes săo as leclas mas que necessitam de mit prianista e uma pauta para origina uma determinada harmonia i.

En resumo, para encurtar uma longa história, a lcitura do ADN re. quer uma instruçäo de comando dada por um ou mais "factores de transcrição" (proteínas que se ligam a uma deterninada zona do ADN com uma scquência particular de nucleotidos - a chamada "TATA box" - à qual se liga também a máquina de leitura (a enzima ARN polimerase II). É a chamada 7ona "promotora". Pode também existir uma série de proteínas ruguladoras (potenciadoras ou inibidoras, que se ligam também em difercntes partes do ADN, antes oul depois da zoma promotora - ver Figura 2.

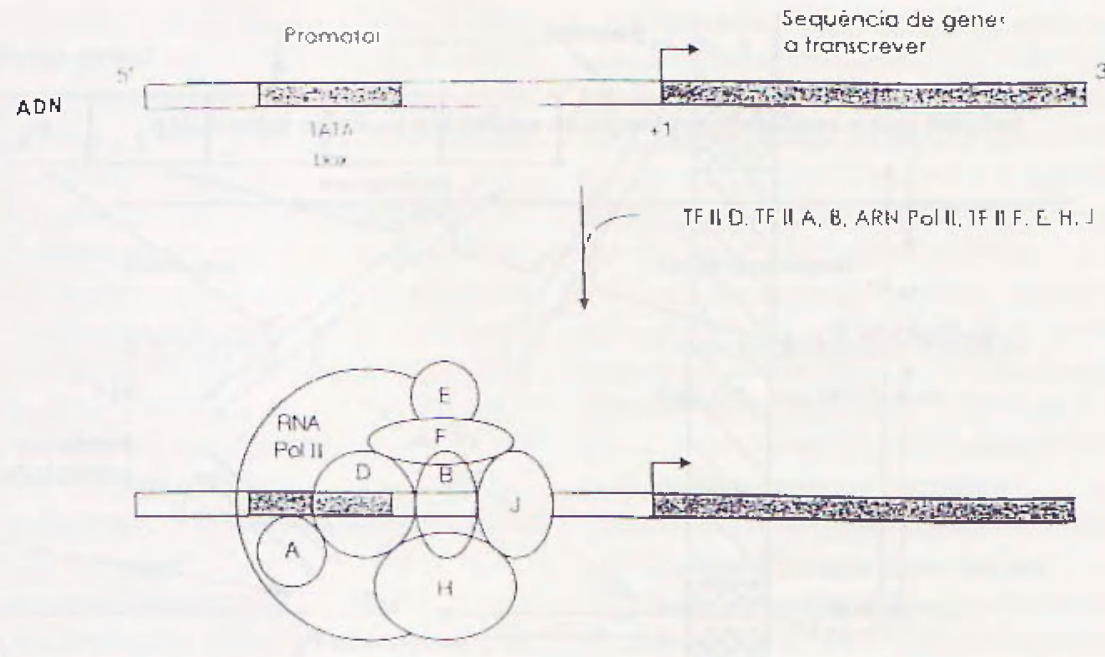

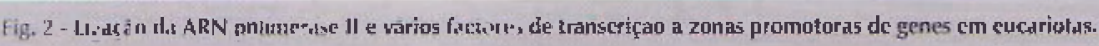

Um mecanismo desia matureza pode ser activado ou desactivado actuando sobre a ligação dos factores de transcrição, c açui existem duas possibilidades: a leitura de genes que codificam a síntese de proteínas requeridas normalmente pelos organismos, ou de genes que codificam a sintese de proteinas só ocasionalmcntc requeridas por exemplo na presença de uma substância estranha, a eliminar). No primciro caso relerimos os genes por "constitutivos" e no segundo por "induzidus" Em qualquer dos casos, uma vec atingido o nível de concentração intra-celular desejato das proteinas em causa, os próprios produlos finais actuam sobre os factores de transcrição determinando a cessação da leitura e a interrupça da sintesc. E o que se chama um processo de regulaçāo por retroacção (fecd-back negativo) ou repressāo pelo produto final cou por oulro produto resultante de $u m$ passo mais avançado do metabolismo em que inlervên as próprias proteínas). Existc, porém, uma diferença: no caso das protcinas constitutivas a cessação requer liga çôes fracas aos factores de transcrição (constantes de associaçāo baixas), pois as respostas devem ster graduais, mas tanto o estímulo para a sínese das proteínas induzidas como a sua repressăo exigem ligaçōes for-
Les (constantes de associaçồcs altas) para que as respostas sejam dadas logo que a causa (substância estranlia) seja detectada ou temlia deixado de constituir problema. Ttm-se. assim, no primeiro caso um controlo gradual amortecido e no segundo um controll. "tudo ou nada".

Começa a tornar-se claro. porém, que quando um agente estranho se torna permantente e passa a ser utilizado pelos organismos os genes induzidos tomam-se constitutivos. As mudanças são consideráveis, representadas por um ADN diferente. o que correspond a uma nova espécie biológica, adaptada à novas condiçöes externas.

Tudo isto é conhecido cm pormenor ao nivel da bioquimica e da genética tradicionais, mas não existe ainda qualquer livro de texto que considere os elemenios químicos. nas formas en que apresentam aos organismos, em termos semelhantes. para alén de uma ou outtra referência ocasionai, de passagem, aos elemenlos tóxicos como o mercúrio oll o chumlu. A literanura sobre o assunto está dispersa nos artigos de investigação originais e os esforços de sinnese sào quase inexistentes, nào obstante a óbvia importância do tema.

Altás, nos textos de bioquimica traticionais, o papel dos elementos quimicos tambérn é tratado superfi- 


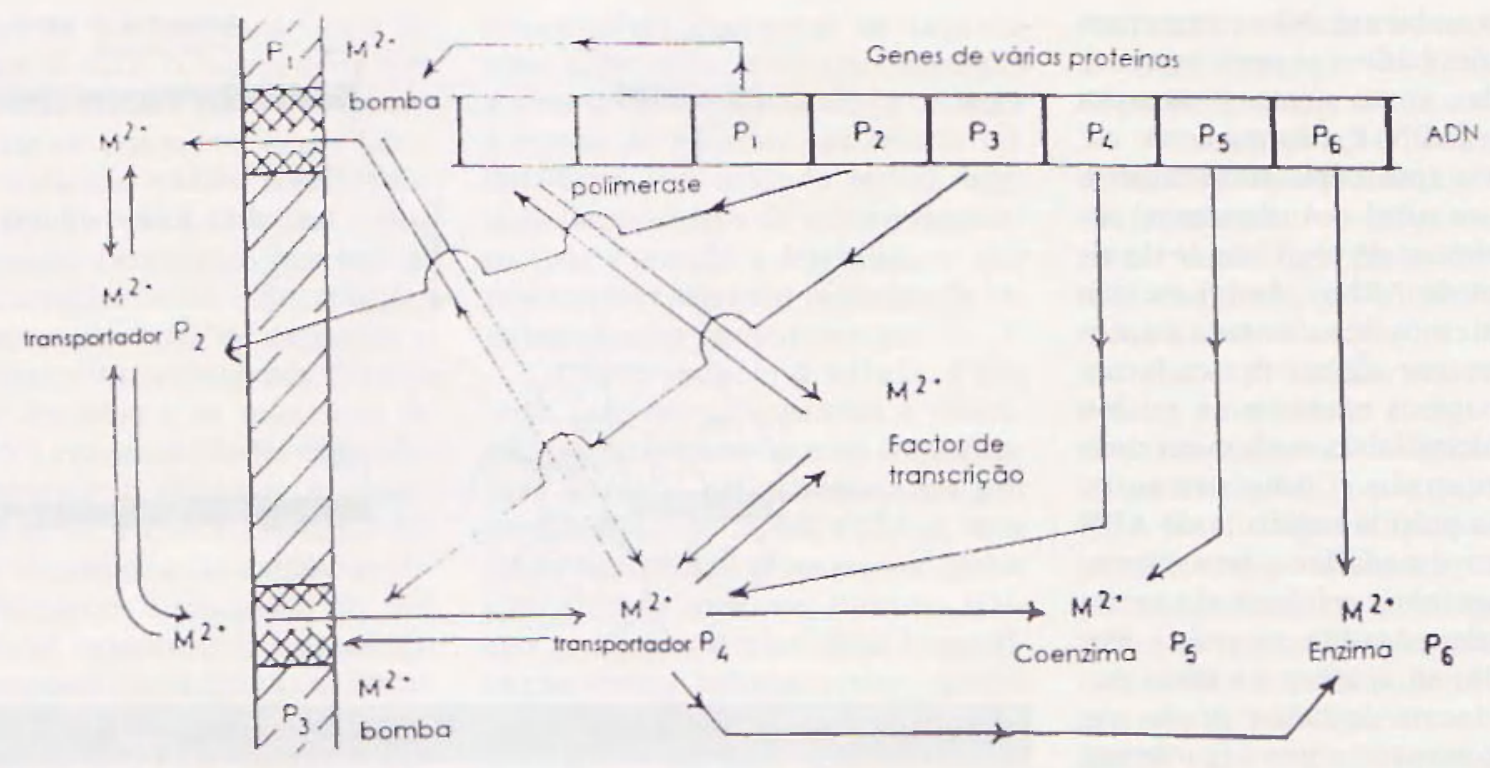

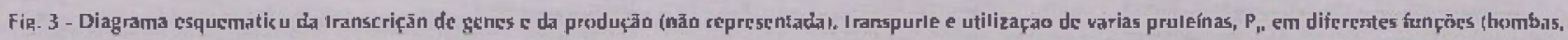
Iransportadures, façares de tramscriçate. coenciahas e enzimas:.

cialmente e sem questionar a razão cie ser cias funçóes de cada um.

O aprofundamento da compreensão da regulaçầo genćtica, atravếs da qual as relações com o ambiente externo se tornam mais claras e racionalizáveis, ainda nāo se traduzitu num tratamento integrado da captura e utỉlização de alguils elementos químicos et rejelçãn de outros. E, todavia, são as proteinas sintetizadas por instruçôes genéticas que inter vên nesses difcruntes aspectos. Să chas que coustituem as metalo-proseínas e metalo-enzinas, as hombas e canais através dos quais passam os clementos, os lilamentos que localizam os compartimentos internos para onde alguns elementos se dirigem. etc. E sāo sintetizadas com esses fins específicos, ver Figura 3.

Como pode o tema ser iralado deixando de lado uma parte conside. rável de um todo que tem de funcionar de forma conjunta c integrada?

Acresce yue, como já referimos e é intutivamcute óbvio, toda a complexa maq̧uinaria de transcrição c depois de traduçầo ao nível dos ríbosomas para obter proteínas nāo lunciona de forma independence para cada elemt'nto, isto é, não trata primeiro du lerro, por exemplo, depois do putássio, depois do cálcio, etc.

Cada elemcinto é reguerido cm simultäneo com todos os outros c em quanidades bem delerminadas. Os seus papéis cruzam-se permanelltemente e tudo tem de ser rugulado até ao mais infimo pormenor. E nāu só os elementus; também a encrigia a utilizar tem de set captada ou produzida em consonăncia com os requisitos de uma rede metabólica complexa. para além da despendida nea captaçăo das matë́rias-primas.

Na verdadc. é fácil comprounder que para garamlitr tuma actividade celular totalmente coordenada e intcractiva, todas as velocidades reaccionais nos difarentes passos metabólicos Lêm de ser compalíveis entre si já quc os produlos de umas reacçōes são matérias primas para àtros. Síntese e degradaçāo ou captura ć rejeiçãu não podem ser processos isola. dos e indepondentes. Nāo pode haver excesson nem acumulaçăn de produtos, como naào pode haver lalta deles, pois imcdiatamente o mecanismo celular ficaria descontrolado e a célula deixaría de ser viávej e morreria. Tudo isto eve evidente, mas a questäo como assegurar c gerir essa courdemaça en termos físicos e quinicos. Nào basta têr una molécula codificadora, um determinado ADN: ele anculas codifica a sintesc de proleinas e dos ARNs necessários para o eleiso. Na realidade o genoma representa " conjunto das proteinas de um urganismo, a que podemos chamar o protemo, mas por si so nāo confere vida. E a máquina que ć necessária, bem como o respectivo combuslivel. e ainda os transportadores/distribuidores de matérias-primas é cucrgia pelos diversos circuitos reaccionais que sāo comulis a vários deles. Um organismo vivo é um sistema dinânico que flut permancntemente.

Por cxemplo. sāo as chamadas coenzimas que distribuem H.C.N.O em substratos convenciomais para os dìlerentes circuitos metabólicos, e a moeda qtiase universal da energia é a molécula ATF, comum à tuasc tutalidade das reaçues melabólicas $\mathrm{e}$ também a outros processos. por excmplo o fumcionamemo das bonbas de sódio, cálcio e potássio (e que desde logo exige magnésio para poder fulcionarj. Nole-se que neste breve apontamento surgt imediata- 
mente uma correlaçào cntrc diversos elementos: C,IIN,O iclementos orgânincos essenciais, a que sc junta o enxolre), o lósforo (do ATP), o magnésio (necessário para que o ATP funcionci, o sódio e o cálcio que o ATP expele e o potássio quc o ATP ajuda a capiurar).

Naturalmentc, porque o fosfato é umi ácido fraco, a acidez celular lica tambrem decidida c ligada aos restanLes requisitos. Mas as correlaçòes não [ican por aqui; pouco a pouco começam a definir-se os requisitos minimos em elementos para un organismo funcionar e a compreender-se como cles estão necessarlamente rclacionados entre si, qualitativa quantitativamente.

\section{OS ELEMENTOS ESSENCIAIS NOS ORGANISMOS MAIS PRIMITIVOS}

Uma célula contén cerca de vinue elementos quimicos diferentes. ver Tabela 2. e o seu luncionamento depende criticamente da forma como csses clementos estão nela distribuí dos. A distribuição relere-se nāo só às espécies químicas e combinaçōes dos elementos mas tambén ao posicionamento destes nas diferentes partes do espaço da célula e ao seu novimento. Uma vez que estas distrỉbuicóes são caractcrísticas dos or ganismos o mecanismo de distribuicão terá de ser altamentc oryanizado.

Como vimos antes, a organizaçào é gerida centralnente (regulada) pclo gunoma, que está em contacto directo ou indirecto com os diferenLes produtos t' matérias primas e con as suas distribuiçós. Adicionalmente. a organizaçāo có controlada através das interacçōes das concentraçōes dos elementos com as bomlyas, canais, transportadores. permutadores e enzimas que movem esses elemenros nas células e alravés das membranas celulares. Todos os vinte elementos são geridos individualmente de forna específica e a sua localizaçäo física e comportamento químico กão sofrem contaminaçăo nem a

\begin{tabular}{|c|c|}
\hline \multicolumn{2}{|c|}{ Elemenłos químicos em células de arganismos primilivos e suas funçōes } \\
\hline Elementes & Funçōes prinçipais \\
\hline H. C.N.O.P.S & $\begin{array}{l}\text { Fornaçāo de polimeras a partir de } \\
\mathrm{H}_{2} \mathrm{O}, \mathrm{CO}_{2} \mathrm{NH}_{3} \mathrm{HPO}_{-}^{-} \text {e } \mathrm{HS} \text {. }\end{array}$ \\
\hline $\mathrm{Na}^{-}, \mathrm{k}^{+}, \mathrm{Cl}$ & Equilibrı osmólico e electroliłico \\
\hline$M g^{7 *}$ & $\begin{array}{l}\text { Calófise äcido-base suave. Funçāes } \\
\text { esliuturais no DNA, RNA. etc. }\end{array}$ \\
\hline$M n^{2+}\left(2 \mathrm{~F}^{2+}\right)$ & $\begin{array}{l}\text { Calálise ácido-bose majs lorte. } \\
\text { Funçōes estrulurdis no DNA. RMA }\end{array}$ \\
\hline V. Fe ${ }^{2-}, \mathrm{Co}^{2 *}, \mathrm{~N} / \mathrm{i}^{2}$, Se, Mo, $[W]$ & $\begin{array}{l}\text { Catćlise Iêdox \{nomalmenle } \\
\text { reduçōo\} }\end{array}$ \\
\hline $\mathrm{Ca}^{\mathrm{i}+} . \mathrm{Si}$ & Relorço de esfiuturas externas \\
\hline
\end{tabular}

competição de outros elementos. O resultado final é um sistema estacionário, homeostático, que corrcsponde a um dado ADN, a Lma dada maquinaria, a tima dada quantidade de cnergia c a uma dada composição de malćrias primas, que está relacionada com a disponibilidade dos elementos no ambiente ém que a célula (ou o organismo) se uncontran.

Se for possivel comprecnder a forma comos os elementos quimico ou as suas combinaçóes naturais simples sc distribuen nas células em condiçöes ambientais distintas pode. remos racionalizar a forma como essa distribuiçăo variou ao longo de 4 biliǒes de anos de cvoluçāo e de que forma está relacionada con as dilerentes espécics biológicas que se originaram ao longo desse tempo. Para cssc objectivo teremos também que conhecer as variaçòes da especiaçäo dos elementos químicos ao longo do tenjpo pots esse é um factor crílico prara possibilitar o seu acesso e captura pelos organismos.

Há aqui. como vimos, duas questōes a considerar: (a) a captura : incorporaço dos elementos. dispo. niveis em diferentes lormas: (b) a disposição destas formas ern difcrentes partes ou compartimentos das cé lulas e dos organismos.

Vejamos a primeira questāo.

Os clementos principais - C.H,O e $\mathrm{N}$ - constituem todas as estruturas celulares e inclucm polimeros como as protemas, lipidos, polinucleótidos e polissacáridos. São moléculas termodinamicamente instáveis mas cineticamente estáveis, requeridas em quantidades determinadas e obviaInconte relacionadas entre si, para nào haver excessos ou faltas, devendo também cxistir una forma de as distrilyuir adequadamente onde são necessárias (cm termos funcionais). Como a composição de cada uma em termos dos elementos C.H.O.N $\dot{C} \mathrm{di}$ ferente também as formas como estes člcmentos são utilizados têt de ser adequadamente distribuídas nos diferentes percursos metabólicos.

A distribuiça faz-se inicialmenle alravés de percursos metabólicos calalisados t" devidamente controlàdos. por exemplo na glucogéncse e 
חa sintese de amino ácidos ou de nuclcotidos, sendo os clementos transportadus por coenzimas moveis na forma de unidades transleríveis, рог exemplo $\mathrm{H}^{-},-\mathrm{CH}_{3} \mathrm{CO},-\mathrm{CH}_{3}$, etc.

Assim, nos organisnos unicelulares prinitivos os clementos incorporados na forma de moléculas simples como $\mathrm{I}_{2} \mathrm{O}, \mathrm{CO}_{2}$ e $\mathrm{N}_{2}$, que passan facilmentc através thos membratlas bjológicas, terāo de ser convertidos nessas unidades transferiveis c ligadas às coenzimas respectivas. UEm organismos superiores, a incorporação de elcmentos dá-se atrałés de moléculas maiores, por exemplo glucose). A subsequcnte construçăo de moléculas cada vez maiores ć também controlada em percursos metabólicos com catalisadores (enzimas) quc reconhecem as molćculas pequenas e as fragmencos inmermediários. A produção thestas enzimas é. obviamente. constimuiva le pode ser ampliada. donde terá de haver re gulaçăo au niverl do ADN. É rambém evidente que as enzimas só operam se houver um fornecimcinto adequado das moléculas jơuconas iniciais e que todo este procosso requer energia. Desı mudo a distribuiçäo dos ćlementos nào é leita un condiçūes dé cưuilibrio tcrmodinânico te o processo é completamente irreversivel. A conergia é assim um repuisito essençal é é distribuida na furma de NTPs, nuclcólido-ırifoslatos, em especial o A CP; Iogicamente lerá também de estar sob controle (por retroacçāo para nầo haver ilesperdícios. Por cestas razōes nāo se jodictá conlcluir quo existe uma relaçāo directa e proporcional entre as disponibilidades extermas dos elemencos e a forma ( $\mathrm{k}$ localizaçäo) em que estes se encomtram nas células. Aliás, as condiçōes variam de organismo para organismo e de célula para célula: os reculusitos foncionais varian cm cada casu e estes sāo naturalmente dencrminantes;

Para alśm dos elementos C. H,N,O outros telementos sāo também utilizadion nos compostos "orgânicos" princijais, designadantute o enxofre e o lósfuro, tăo essenciais como us primeiros.
Fxaminemos primeiro estus dois casos e depois us elementos de transição requeridos pulos organismos primilives.

\section{I Enxolre}

O enxofre laz parte dos proces. sos merabólicon de todos os orgarismos; recordemos qui a amostera primitiva tinha um toor elevado de $\mathrm{H}_{2} \mathrm{~S}$ e a Terra uma presença assinalável de sulfuretos. O reor do sulfureto no mar era também apreciável. Assim não surpreendem as scguintes obscrvaçōes:

a) As sinteses de proténas sāo na sua maioria iniciadas for um aminoácido tioétce - a metionja (em eucariotas. on formil metionitha en procartotas) - que depois ć Irequeutemente temovida:

b) A transterticia de grupos acilo ce metilo é baseada em tióis tcisteina) ou lio-cheres (metionina):

c) O controle do balanç cutre material urgànico ixidado e reduzido é assegurado através da cisteína ou da glutationa:

d) Grupos tiolato, -S', estäo presentes no centro activo de muitas encimas:

e) Muito do "cross-linking" de proténas é assegurado por poutes dissulfureto $-\$-5-$;

f) Muitos percursos de transporte electrónico possum centros $\mathrm{Fc} / \mathrm{S}$ :

g) A captura de $\mathrm{H}_{2}$ é baseada em agregados Ni/fels ull Fuls a captura do $\mathrm{N}_{2}$ é baseada em agregados Mo/Fe/S, V/Fe/S ou Fe/Fe/S;

h) Acrualmente o cuxolre é capturado via sullato ce incurporado como tal en polissacáridos c* prateínas. mas a reduçăo de sulfato a su]fureto é tambén corrente. Lem lugar no espaco periplasmático c* utiliza enzimas de Fe e Mo quc incluem enxolre. A ligura 4 mostra os metais envolvidos na captura do sullatu (Mo,Fe.Co), desde logo pondo em evidência a essencialidade destes metais c' a sula correlaçäo.

A regulaçào do enxolre é leita ao nivel dos gencs pur retrojaçãa baseada em factores de transcrição conucndo este elentonio, cono a metio-

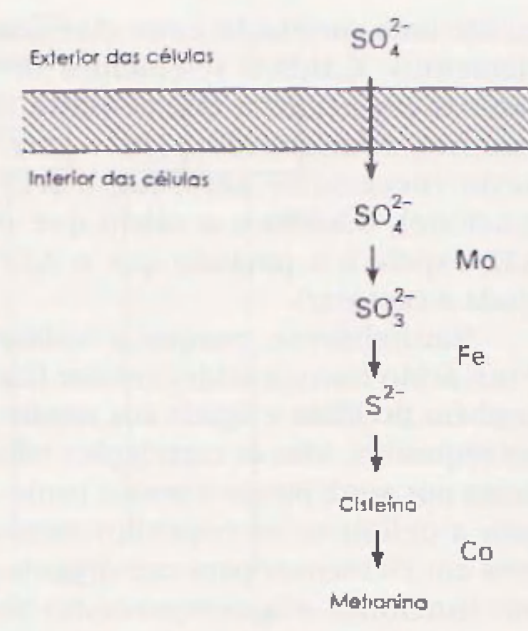

Fie. 4 - Elemen los quimio us envolvidos na captura de silfato por céluirs.

nina. a cisteína ou a S-adenilmetiothina. O processis é complexu e tcm algumas semellanças cim o processo de fixação do azoto pur acção da nitrugenase.

Ë tolavia curioso notar nuc enquanto a incorporaçäo dos clementos C.Fl,N.O a parió das pequetas moléculas simples após difusāo aıravés das mentranas é inteiramente baseada na ligaçäu covalente de Iragmentos transportados por coenzimas. a incorpuraçà de sullato - na torma de lầo SO ${ }_{4}^{2-}$ - necessila transporladorés deste iâo nos fluidos extracelulares inos organismos superiores), que possam passá-lo através das membranas utilizando hombas. Ora o tenr dó sulfato disponivel näo é tāo garantido como o de $\mathrm{ll}_{2} \mathrm{O}, \mathrm{CO}_{2}$ e $\mathrm{N}_{2}$ na que há gue asscgurá-lo. mas o processo nāo podc envolver ligaçöes covaluntes fora das células quc o iâo terá de ser [acilmente libertado a entrada da colula e transportado como tal para o scu interior. Noste casu, como no da maioria dos restantes elememtos, o processo tem dc envolver ligaçōes iónicas com proleinas num equilíbrio termodinàmica que näo pode ser conirolado. Assim1, são as próprias proteinas das bombas que estão sol controle. rêlacionado com a concentraçäo intertia de sulfaio, anres de qualquet arans- 
[ormação e inscrção posterior em moléculas covalentes. Obviamente, todos us pruccssos - coptura, transporte, trans[ornuçào e incorporaça tm moliculas covalentes - têm de cstar em total harmonia e sảo regulados ao nivel dos genes, lal como antes foi referido. Una vez mais é пeccssáro despender energia, e como é evidente todos estes processos estão relacionados com a incorporação de II,C.N.O e. como se verá adiante, com a incorporação de uma série de elementos "inorgânicos", desde logo os utilizados nas bombas e na redução do sultato.

\subsection{Fósforo (fosfato)}

O fósforo é, curiosamente. um elementu central nos organismos vivos. Para confirmar esta ideia hasta notar que está presente (como fosfato) nos ácidos nuclcicos. $\mathrm{ADN}$ ARN's, nos transportadores de energia. NTPs e especialmente o ATP, várias coenzimas, NAD, FAD, FMN. em línidos de membranas, em molëculas sinalizadoras como o AMP cíclico e o $\mathrm{IP}_{3}$, sendo ainda utilizado em processos de fosforilação (catalisada por quinases) e desloslorilaçăo (catalisada por loslatases), essenctais em regulaçāo. A análise das razōes da selecçäo do grupo fosfato para todas estas funções justificaria por sì só uma outra conferência e näo pode ster fcita aqui. Note-se, porém, que esic grupo cstá presente já nos arganismos mais primilivos e o conjunto de funçỏes que desempenha năo poderia ser atribuido a mais nenlu urr outro elemento por razoes essencialmente químicas.

O fostato é processado de forma muito semellante ao sulfato (e ao molibdato) no que se relere à sua entrada nas células, mas já antes do advento do oxigénio. A cntrada dáse passivamentc através de canais de fosfato, mas imediatamente após a entrada é incorporado covalente. mente numa grande variedade de ésteres e anidridos orgânicos sem alıerar o estado da oxidação do fósforo. A distribuição do fosfato é largamente feita em compostos covalentes. qü [uncionam como ou comunicam com taciores de transeriçào c com o transporte através das menubanas (via ATP, energia). Só os passos iniciais de capeura c iramsportc covolvem ligaçōes iónicas em cquilíbrio temmodinâmico. Bastaria notar a presença de foslato no ATP (c nos NTPs em geraly para concluir que o fósforo esıá ligado ao metabolismo de todos os clementos biológicos, em especial àqueles que exigem energia para o respectivo transporte alravés das membranas biológicas ou estão associados ao funcionamento do propris ATP. como é o caso do $\mathrm{Mg}^{2+} e$, indirectamente, do $\mathrm{H}^{+}$, que condiciona a ligaçāo $\mathrm{Mg}^{2+}$.ATP'- Não surpreconde. assim, que us lcores de ATP e fosfato sejam lixos para cada estado metabólico e cada tipo de célula, pois só assimn se assegura a coortenação de todo o metabolismo. É o que designamos por bomeoslase dinâmico.

Naturalmente, tamben o $\mathrm{Ca}^{2-}$. o $\mathrm{Na}^{+}$e o $\mathrm{Cl}^{-}$que são bombeados para o exterior das células estäo directamente relacionados com o teor de ATP $^{2}$, indirectamente, o mesmo acuntece ao $\mathrm{K}^{+}$, estrcitamente ligado au $\mathrm{Na}^{+}$c à manutençāo de neutralidade celular.

Incluindo os elementos constit utivos já referidos - C.H.N,O.S - c adicionando $\mathrm{P}, \mathrm{Na}^{+}, \mathrm{K}^{+}, \mathrm{Cl}^{-}, \mathrm{Mg}^{2} \div, \mathrm{Ca}^{2-}$, Itrnus já um conjunto de 11 elemenlos essenciais à vida a iodos correlacionados entre si.

\subsection{Elementos de transição}

Sabemos. por análise. guc us organismos primilivos possuem. alćm destes, alguns elementos de transiçäo, designadamente Mn. Fe. Co, Ni, Mo, W(Zn), e Se, A medida quc 0 ambicnte se tornou progressivamente mais oxidado, o que requer uma cnzima com Mn para a produçāo de oxigénio, $\mathrm{O}_{2}$, vieram adicionar-se a estes outros elementos que os organismos se viram forçados a utilizar, em especial o $\mathrm{Zn}$ (mais disponivel) e o $\mathrm{Cu}$.

Deixando de lado, por enquanto, os elementos que se tormaram disponiveis devido à progressiva oxigenação da atmostera e consequerı oxidação dos sulfuretos, caberá per- guntar porque razão os oulros clcmentos de transiçào acima referidos sāo necessários à vidà.

Desde logo deverá notar-sc quc o ATP (ou outros nucleótido-trifosfaLos) sāo transportadores de energia na forma de ligaçōes instáveis, mas nảo sāo a fonte de encrgia. Esta terá de vir ou dez radiaçáa solas on de ouaros compostos químicos, eventualmente resultando na formaça de gradientes de $\mathrm{pH}$ que origimam posLeriornlemte o ATP fou outros compostos transportadores de energia como os tioésteres).

Ora cstes processos geradores de energia envolvem, em algumas lascs. reacçōes de redução (por cxcmplo do $\mathrm{CO}_{2}$ ) e lransportc de clectróes, a que requer catalizadores adequados.

Deveră também existir una ligaçào às reacçōes de reduçāo que ocorren no citoplasma. dominadas por compostos sulfurados, por excmplo glutationa e tioredoxina. Tambem a captura de $N_{2}$ exige a sua posLerior reduçào a compostos aminados, o que laz intervir dois dos elemenros referidos, o molibdénio lou o vanádio e o [erro) e indirectamente o selénio la tioredoxina reductase. necessália para reduzir ribose a deoxiribose na síntese do $\Lambda \mathrm{DN}$, é uma enzima de selénio).

Restanos justilicar a presença nos organismos mais primitivos de $\mathrm{Zn}^{2+}, \mathrm{C}_{0}^{2}+$ e $\mathrm{Ni}^{2+}$, bem como de $\mathrm{W}$ cm algumas arquehactérias.

O $\mathrm{Ni}^{2}+$ e o $\mathrm{Cr}^{2}+$ sāo, de tacto. elementos "primitivos" que tendem a desaparecer dos seres vivos mais evoluídos. $0 \mathrm{Ni}^{2+}$ é essenciol nas hidrogenases, enzimas que catalisam a reduçào de $\mathrm{II}_{2}$; nos organismos acróbicos está resırilo a uma enzima - a urease - que os animais superiores näo possuem.

Quanto ao Co2*, transportador de grupos $\mathrm{CH}_{3}$ quando incorporado num ancl fechado, a corrina, como na vilamina B12, éstá directamente cnvolvido na remoçäo do primeiro arninoácido das proténas - a metionina - conforme antes referido. iA remoçăo do grupo formil nos procariolas cxige uma conzima de ferro). Finalmente o $z_{n}{ }^{2}+$ é um excelente 
calalizador de reaccổes ácido-base (nolar que o $\mathrm{H}$ - está prescntc em concentraça mulo baixa, $10^{-7} \mathrm{M}$ ) e embora pouco abundante іпісіalmente deve ter sido mais tarde capturado para esse efeito, em alternativa mass elicaz ao $\mathrm{Mg}^{3-1}$, presente concentraçóes da ordem dos $10^{-3} \mathrm{M}$. c utilizado sobretudo fora do citoplasma.

Scm avançar mais nesta enumeraçāo de necessidades e funções desempenhadas, o que requereria dcmasiado tempo. desde já é possível ver as interclaçōes de todos os elementos referidos, que levam a uma homeostase (dinânica) das suas concenıraçócs - Tabcla 3.

\section{DESENVOLVIMENTOS NA UTILIZACĀO DE ALGUNS ELEMENTOS: CÁLCIO, MANGANES, ZINCO E COBRE}

Un primeiro desenvolvinento. provavelmente anterior à evoluçăo do oxigénio ou acompanhando os scus princiros estádios, terá sido a mudança no papel do iäo Ca $2 \div$. Como dissemos antes. este ião é rejeitado do interior das células por se poder combinar facilnucrite con centros de carga negativa bloqueando a sula acção. Entre esses centros estão. designadamente, os acidos rucleicos - ADN e ARN - e as prolcínas. No exterior, os iós Ca2- reforcarañ as membranas, uma vez mais por com binaçòes corr grupos arrcgados, ou formaram precipitados com o iâo carbonato, como se podc ver ainda nos rachedos de coral a nos estromatolitos. O descnvolvimento seguinte. já corn cucariotas unice|ılares, foi a formação de conchas e outras estruturas cristalinas como nos foraminileros iprecipitação de $\mathrm{CaCO}_{3}$ direcıamente da água do mar) e nos cocolitos, em que as correspondentes unidades so formam já em vesículas internas posteriormente enviadas (por exocilose) para o exterior.

Nos probozóías unicelulares surgiram tambén outras lunçoes associadas ao cálcio, por exemplo o movimento dos célios das paramécias e a contraçăo das vorticelas ique não pode deixar de recurdar a contracçào muscular nos animais superiores). Os fermentos. que säo fungos. Inostram já sistcmas de controlo de cálcio bastante desenvolvitos, designadamente utilizando gradientes de concenıração para diversas funçōes. O miesmo acontcce nas plantas, que surgen chetre os primeiros urganismos pluricelulares.

Neste caso os gradientes de concentração envolven o citoplasma [2 0

Tobela 3

Elementas químicas envolvidos em diversos processos melabólicos

\begin{tabular}{|c|c|}
\hline Controle osmólico e de carga & $\mathrm{Na}^{+}, \mathrm{K}^{*}, \mathrm{Cl} \cdot \mathrm{Co}^{2+}$ \\
\hline Calálise dcido-bose & $\mathrm{Mg}^{-1}\left\{Z \eta^{2}=\right\}$ \\
\hline Eolanço ácido-base & $\mathrm{H}^{-} . \mathrm{HPO}^{2}$ : ATP \\
\hline Bulanço redox & $H, F e, S .5 e,\{w\}$ \\
\hline Sinlese de proteinas & C. H. N, O, Fe, Co \\
\hline Fixaçôo de azoto & Mo. Fe, 5 \\
\hline Movimentos de cilios e contracçoes, etc. & $\mathrm{Ca}^{2}$, ATP, $\mathrm{Mg}^{3+}$ \\
\hline
\end{tabular}




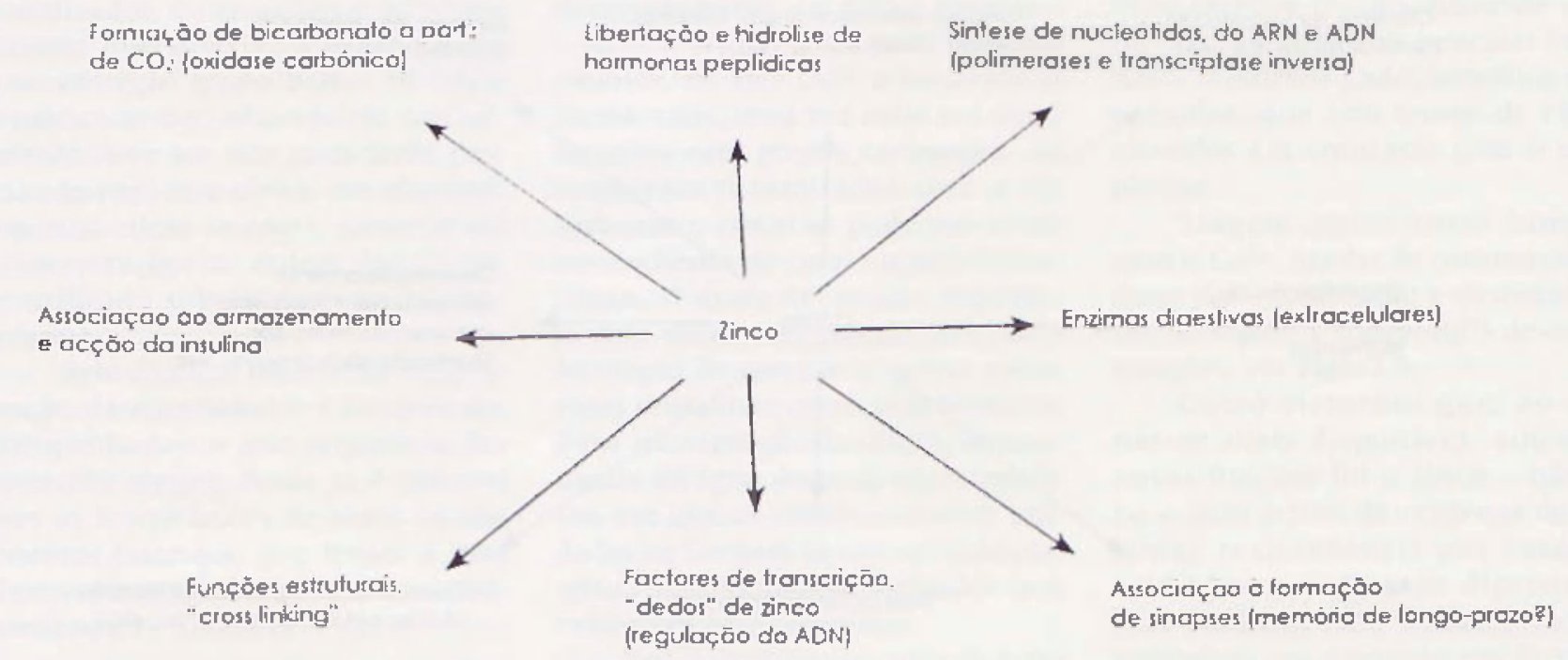

Fig. 7 - Exemplas de funçî̌es bielúgicas du zinco.

duzidas por oxidaçāo catalisada por enzimas de ferro ou cobre. demonstrando Imma vez mais a inter-relação das lunçōes dus elementos químicos.

Para além destas funçōes, o zinco desempenha alyumas outras de importância e numiteru crescentes, ver Figura 7. sendo lwoje considerado uma espécie dı lıormona inorgânica. Na baš da sua utilizaçāo estāo o lactı do metal näo softer oxidação ou redução ce o de sc liggar fortemente a ceniros de proteílas das quais näo permula lacilmentc, sobretudo se forem rígidas to que năo acontuce com os dedos de zinco). Em alguns casos o zinco lorma apenas ligaçōes fracas em vesículas, por cxemplo associando-se a moléculas como a insulina, mantendo-se disponivel para funcionar conno ião $\mathrm{Zn}^{2+}$. No citoplasma celular, como se disse, é de assinalar a relaçäo com a síntese e degradaçăo do ADN/ARN usando enzimas (nucleases) em que o metal se liga fortemente a cembros coordenantes N/S. Outras enzimas rclicvantes no citoplasma são a sujeróxido-dismutase de cobre ce zinco (que substituiu as superóxido-dismutases de ferro e manganés dos procariotasj com 4 doadores azotadus, et a anidrase carbónica. com 3 doadores azotados e um de oxigénio. Qualquer delas nâo permu. ta o zinco facilmente, o que wbvia aos riscos de competição deste netal con outros e a actividade degradarjya nagyutele compartimento.

Outro elemento que se tormus disponivel após a emergência do dioxigénio foi, como jä relerinos, o cobre.

A importancia funcional do cobre deriva de duas particularidades deste elemento.

Por um lado, embora o ferro tenha conhecido uma importância acrescida na química a potencial redox clevado de moléculas como $\mathrm{O}_{2}, \mathrm{H}_{2} \mathrm{O}$. NO. ctc., fora da célula, o $\mathrm{O}_{2}$ e $\mathrm{H}_{2} \mathrm{O}$ são majs lacilmente manuseados com cupro-cinzimas pois o lerro (mesmo hémico) é susceptivel de ser oxidado. Por outro lado, o $\mathrm{Cu}^{2+} \mathrm{c}$ especialmente o $\mathrm{Cu}^{-}$formant ligaçōes fortes con ligandos contendo doadores $N$ e $S$, o que permite a exportação das entinas en sistemas com potenciais redox mais próximos do sistema $\mathrm{O}_{2} / \mathrm{H}_{2} \mathrm{O}$. Em particular. entre outras funçōes, ver Figura 8 , as enzimas de cobre passaram a ser utilizadas fora das cúlulas para catalizar a oxidação de grupos tiólicos formando dissulfurctos e provocando o "cross-linking" de proteínas, estabilizando assim o tecido conjuntivo. Desie modo, células c órgãos pudt'ram organizar-st: tm estruturas mitilticelulares.
Conno us requisitos de crescimento exigem que as libras do tecido conjuntivo tenham de ser quebradas antes de voltar a ser refejtas, o zinco em enzimas uxtracelulares encarrega-se da primeira tarefa. A vida multicclular exige assim a corneração destes dois metajs. Cu c $\mathbf{Z} n$, a que se vem juntar o Ca. estabilizador das estruturas formadas, ver Figura 9.

\section{EVOLUÇĀO DAS FUNCŌES DO VANADIO, MOLIBDÉNIO. SELÉNIO E TUNGSTÉNIO}

A ocurréncia de vanádio com estados de oxidacăo crescente trm apenas algumas espécies particulares de organismos de origem cada vitz. menos ancestral na cscada evolutiva - +2 numa nitrogenase alternativa de bactérias, + 3 en certos tunicados (protocordadus) como a Ciona intestinalis, + 4 em certos lungos como a Amanita musiaria e +5 em haloperoxidases de algas vermelhas e castathas, sugere gute sc trata de um elemento cuja utillzação dependeu apenas de características ambientais locais, nāo parecendo ser verdadeiramente essencial. Em organismos superiores (como os seres humanos) há alguns regisios de deficiências assuciadas à sua carência em dieıas es- 


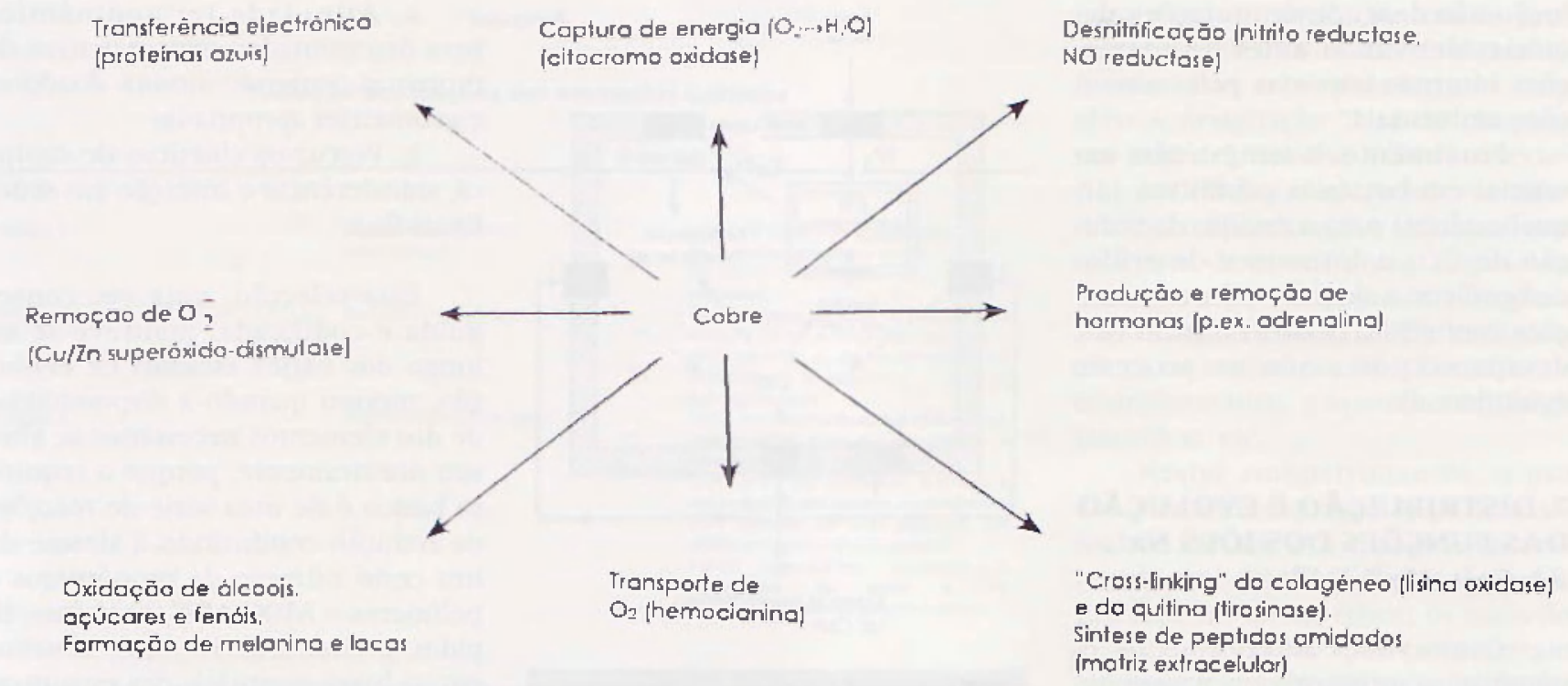

Fi... 8 - Exetazplos de fuaçôes biológicas do cobre.

pecificamente preparadas e de efeitos metabólicos rusultantes da sua administração tcrapếutica (por exemplo um tefeito mimético da insulina). mas as razões da sua essencialidade กão cstăo ainda perfeitamentc esclarecidas.

Quanto ao molibdénio, antes utilizado essencialmentu tla nitrogenase para fixaçāo do azoto (funçāo que se mantém). passou também a ter un papel fundamental cm reacçōes de oxidaçāo-redução envolvendo dois electrōes, por exemplo a redução de sulfara a sulfito ou a reduçào de nitrato a nitrito no espaço periplasmático, ou outras répuerendo também a translerêncla de átomos de oxigénio de grupos MoO ligados a dois tiolatos no centro activo das molibdeno-enzimas.

No caso do selémion verificou-se uma evoluçăo paralela à do molibdénio. Inicialmente este nāo-metal loi utilizado em reacçôes de transferéncia de hidreto. sendo mais eficaz. para este tim que o enxolre. Com o advento do oxigénio $(0$,$) , o papel$ do selémio passou a ser o de casalizador para a remoçắu de peróxido e de iodo ligado (covalente) na hormona cia tiróide, a tiroxina. Uma vez mais se verilica aqui que a cvo-

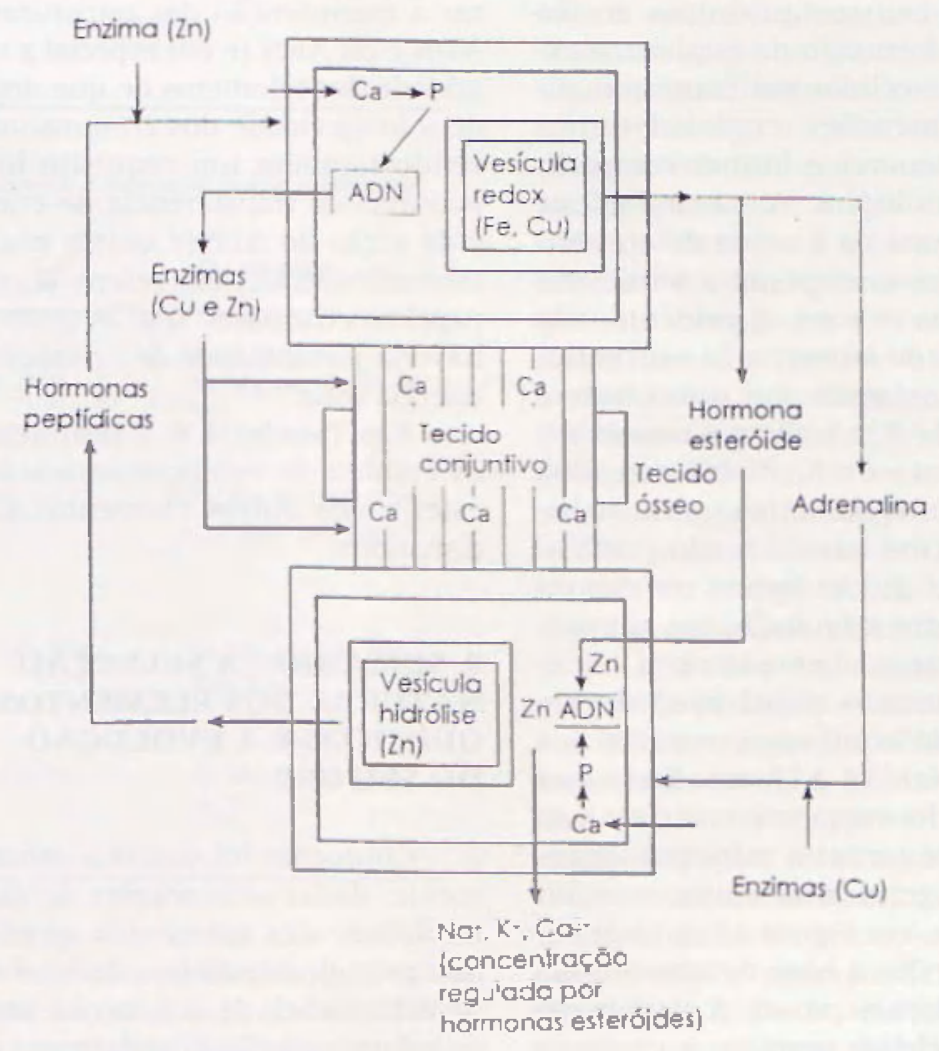

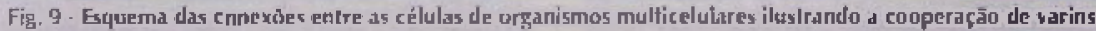

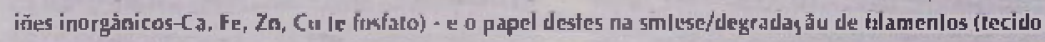
conjintiva) e hormonxs. 
lução nāo dẹpende de mutaçōes aleatórias derivando antes de adapıaçōes internas impostas pelas alteraçōes ambistlais.

Finalmente, o iungsténio, essencial cm bactérias primilivas tarqucbactérias) para a catảlise da reduçāo de $\mathrm{CO}_{2}$ a formaio c de ácidos carboxílicos a aldeídos, não tem lunçōes conhecidas noutros organismos. desaparcendo assim no processo evolutivo.

\section{DISTRIBUIÇĀO E EVOLUÇĀO DAS FUNÇŌES DOS IÕES Na+, $\mathrm{K}^{+}, \mathrm{Ca}^{2+}, \mathrm{Mg}^{2+} \mathrm{E} \mathrm{Cl}^{-}$}

Como vimos anteriurmente, os urganismos primuitivos rejeitaram necessariamentc os jōes $\mathrm{Na}^{\circ}$, $\mathrm{Ca}^{+}-\mathrm{e} \mathrm{Cl}^{-}$. enquantu que o $\mathrm{K}^{+} \mathrm{e}$ o $\mathrm{Mg}^{2+}$ eram concentrados internamente. Este lacto levou ao reforço das membranas celulares externas pur ligação dos seus centros aniónicos ao ião $\mathrm{Ca}^{2 \tau}$, e à formação de esqueletos externos. As células puderatr aumenlar de dimensões, englobar uutras cólulas menores e formar compartimentos múlaiplos. A nosso ver esıe processu está na base do ơcsenvolvimento dos elicariotas a partir dos procariotas e, como é evidenlc, nảo dependeu do aumento da concentração de dioxigénjo. Por oulro lado, a rejeição de $\mathrm{Na}^{-}$e $\mathrm{Cl}^{-}$e a concentraçăo interna de $\mathrm{K}^{+}$fornceem uma lonte de encrgla, uma espicie de bateria clectrolítica utilizando gradienles $\mathrm{Na}^{+} / \mathrm{K}^{+}$que se tornon um dos $\mathrm{re}-$ quisitos para a cvolução dos animais. 0 uso deste gradiente obrigou ao desenvolvimenuo simulaăneo de um sistema de hombagem especial - a cnzima $\mathrm{Na}+/ \mathrm{K}+\mathrm{ATP}-a \mathrm{se}$. Toda usta ¿voluçāo fol cooperativa: o $\mathrm{Ca}^{2+} \mathrm{aca}-$ bou por se tornar o principa! segundo mensageiro intracelular, a seguir ao fusfato, ver Figura 10. c os gradientes $\mathrm{Na}+\mathrm{K}-$ a base de transmissão dos impulsos nervosos. A conjugaçāo dos dois efejios permitiu a evoluçăo do sistema nervoso dos animais e. subsequentemente, do cérebro. Por seu lado. o $\mathrm{Mg}^{2}$ passou a activar internamente värias enzimas, a assegu-

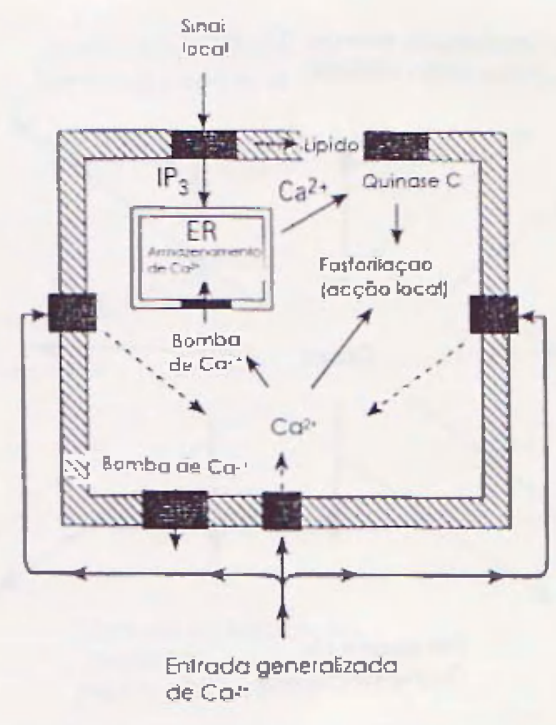

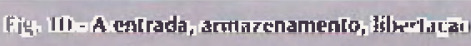

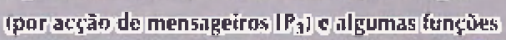

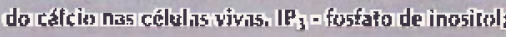
ER - retículo cadoplismálico.

rat a manutenção das estruturas do ADN e do ARN (e em especial a integridade dos telomeros de que depende a longevidade dos cromossomas). sendo também um requisito indisfrensavel da transferencia de cmergia c da acção do ATP te outros nucleótido-trifosfatos), sem referir já o seu papel nas cloroftlas, sem as quais nā haveria possibilidade de utilizaçāo da energia solar.

Nas Tabelas 4 e 5 resumem-se os estádios de evoluçăo assuciados a estes e aos outros elementos antes disculidos.

\section{SUMARIO - A SELECCĀO NATURAL DOS ELEMENTOS QUÍMICOS E A EVOLUÇĀO DO SEU USO}

Conforme loi descrito sumariamente, dadas as condiçōes de dispunibilidade dos clementos químicos rtos primeiros estádios de evoluçăo da vida (Tabcla 2), a selecção, captura e incorporaçào dos elementos rcqueridos no citoplasma dos organismos vivos iprocariotas unicelulares) fol conseguida através de dois pro. cessos: a. Afinjdade tcermodināmica para delurminados contros aclivos de proteinas contendo ítomus doadores e geometrias apropriadas

b. Percursos cinéticos de captura. Iranslerêtncia e inserçāo cm sedes finais lixas

Esı selecção, uma vè conseguida e codificada, manleve-se ao longo dos vários estádios de evoluçào. mesmo quando a dispunibilidado dos elementos necessários se alterou drasticamente. porçuc u regutisito básico á de uma sciric de reacçós de reduçầo conduzindo à sintese de um cerro número de munúmeros e polimeros - ADN. ARN. proteinas, lípidos. polissacáridos - . quc consliı uem as bases essenciais das eseruturas e melabolismo dos seres vivos. Como refictimos antes, a conclusão a exurair $\mathbf{b}^{*}$ que a evoluçâo dépendeu largamente $d c^{\circ}$ adiçōes (dcrivadas das aiteraçōes ambientais) e nāo de substituiçōes nus percursus meiabólicos do citoplasma, o que si assemelha a uma espécie de re-engenlaria organizacional. Naturalmente uxistem exccpções. mas é evidenc yue os principais proccssos metabúlicos se mantiveraun - ver Tabela 1. Isto significa que existe a neccsidade de assegurar alue o ciloptasma de todas as células tcona aproximadamenté a mesma cuncentraçào de iōes metálicus, näo obstante as variaçō's ambientais externas.

Deste Inodo, os novos processos de incorporação desses elcimentos ou de novos ckementos nāo pudem interterir com os existentes. pelo que deverāu scre, essencialmùnte, processos cinticos em que os clementos não permulam (b, acima). $\mathrm{Sc}$ assim пӓo for, e se se mantiverem processos baseados erl afinidade termodinẩmica (a, acima), entāo rlãu poderâo ser introduzidos nuvos centros com aliufdades por elementos metálicos mutu diferentes, (1) ane a teraria (por completiçäo) lodos us processos anteriores. Este é o principio essencial da homeasrast celular: tmanutençăo da concentração dos difurcutes elementos duntro de certus limiles mesmo num sistema abcro e sujeito 
Tabela 4

\section{Evoluçāo das funçāes dos elementos químicos}

\begin{tabular}{|c|c|}
\hline Estádio I & 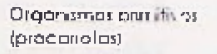 \\
\hline Fitadio ? & Euc ano'as unicelult-a: \\
\hline Estadio 3 & Organismas multicelulo \\
\hline
\end{tabular}

Tobelo 5

Principcis alteraçōes nos iōes meláliços e moléculas peque nas ao longo da evoluçāo biológica

Tempo $x 10^{\circ}$ anos

Principais moléculas pequenas e elementas quínicos ulilizodo

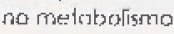

Moléculus pequenas

loes metolicos

$4.0-3.15$

$3.0-2.5$

$\left.\mathrm{CO}_{2}, \mathrm{~N}_{2}, \mathrm{SO}_{2}=\left\{\mathrm{NO}_{3}\right\}, \mathrm{H}_{2} \mathrm{O}, \mid \mathrm{O}_{2}\right\}$

$\mathrm{CO}_{2}, \mathrm{~N}_{2}, 5 \mathrm{O}^{-}, \mathrm{NO}_{3}-\mathrm{H}_{7} \mathrm{O}, \mathrm{O}_{2}$
MgFi/ATP contralam lostorilaçōes Fe"- controla equillarios re dox Na' $/ \mathrm{K} / \mathrm{Cl}$ conirolam a pressc̄o Dymbick

Co- conilrad e:"ado: actwodas e

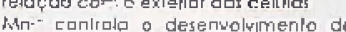
gagorasmas relacianados com or "tuturask plantas

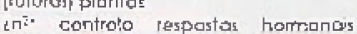
relacionadas cam a crescimenia e deserivolvimenlo dos angrismas.

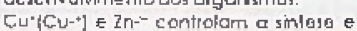
degradactān dos tecidor conjuntivos. Ca.- ardauire sinalizaçūo como $2^{\circ}$ menuagẹiı. Nath (pradier.les) Presidem fransmissua do simais derenvalvimento jo ditomo narvoso. 
influência mais pronunciada na evolução das espécies biológicas à medida que o ambiente se cornou progressivamente mais oxigenato. na sequência da evolução anterior em organismos anaeróbicos que foi dominada por processos de simbiose. e sem esquecer o $\mathrm{Ca}^{2}+, \mathrm{o} \mathrm{Na}^{2}+\mathrm{c}$ o $\mathrm{K}^{*}$. com um papel igualmente determinante, por exemplo no desenvolvinento do sistema nervoso e do cérebro. mas nāo direclamente dependente da maior oxigenaça ambiental.

Como é evidente, se qualquer elemento actualmente nâo utilizado se vier a tomar disponivel no ambiente. a primeira reacção dos organismos vivos será lralá-lo como um tóxico indesejável. rejeitando-o ou neutralizando-o (por exemplo, por hombagem para vacíolos), c a segunda será utilizá-lo como indicador da sua própria presença. permitindo à célula a expressão de proseínas induzidas para lidar com cla. Esic foi c é o caso dos mictais pesados como o $\mathrm{Gd}^{2+}$, o $\mathrm{Pb}^{2+}$, a $\mathrm{Hg}^{2+}$. eic. Eventualmente, no caso da sua presença se tornar permanente. poderá ser ulilizado como mensageiro e mesmo assumir funçồes necessárias. tornando-se um novo componente essencial, devidamente codifjcado, para um novo sistema químico. isto é. uma nova espécie de orsanismo representata por um ADN ligeiramente modificado, mas cm que a química anterior ć largamenle mantida. Como dissemos, a evoluçào dá-se predominantemente por adiçôes, năo por substituições. Os casos do dioxigénio. do cálcio. do zinco é do cobre, que analisámos. são excmplos desıe tipo de evoluçăo, normalnucinte referida como "natural" por ser determinada pela selecçäo "natural" de clementos presentes no ambiente.

Esles argumentos podem, porém, ser estendidos a uma evolução derivada da progressiva major disponibilidade de elementos por acçāo anlropogénica, por exemplo aluminio, resultante da acção corrosiva das chuvas ácidas ou elamentos radioaciivos... Será também uma evolução "nalural" una vez que a especie que originou as altcraçós ambicnlais corrt'spontentes é, em cermos cvolutivos, apenas is5o mesmo - uma determinada es pécie biológica. Não é diferente. para este eleito. das cianohactérias que deram origem ao aumento explosivo do dioxigénio, con as consequências que descrevemos. A conclusão a tirar é ónvia e segue as liçôes de História. Se tal acontecer muitas espécies existentes poderāo deixar de ser viáveis e extinguir-seào, oulas poderão subsistir mas cm nichos protegidos em que sejam preservadas as condiçōes ambientais anteriores como acontece com muiros microorganismos anaeróbicos actuais que continuam a existir. a reproduzir-se, a tevoluir e a diversificar-sc en condiçôes rigorosamente anóxicas, como nos lodos lacustres, nos pântanos ou no rumen das vacas) e finalmeme outras poderào "aprenter" a usar os novos elementos e dar origen a espécies adapradas às novas condiçōes ambientais e consequentemente mais viáveis. A espécie humana poderá seguir um ou mais destes caminhos. mas a sua presença fulura poderá estar em risco por sua propria culpa:

Chegámos ao fim da nossa exposiçäo. sucinta e recessariamente superficial como tivenos ocasiâo d: salientar. De alguma forma tratousc de una história da cvolução das espécies no nosso plancra. Todavia. não se cingiu aos clássicos dados de observaçăo morfológica, ainda que os mesmos estejam sempre presenıes, não considerou o genoma como o motur da evoluçäo e sim como a sua representaça isem deixal de reconhecer o seu papel fundamental na regulaçăo do metabolismo e manutenção da homcostasc celulary, e nảo se centrou na análise das proteínas e enzimas da cada espécic uma forma de reconhecimcnto dos genes efectivamentc cxpressos. embora tenha dado relevo ao papel instrumental do proteoma na consilLuiçào da indispensável maquinaria celular e no controle das reacçōes melabólicas. A nossa historia incidiu, sim. sobre o papel central dos clcmentos químicos utilizados pelos organismos vivos. especialmente certos metais, presenres em concentrações mantidas dentro de faixas cstreites em cada esjoćcic, c nas suas variaçōes condicionadas pelas mudanças ambientais, originando espécies distintas, de complexidade crescente, ao longo dos biliöes de anos de evolução.

É. assim. uma hisıória que Ioma o metaloma lque nos seja permitido o neologismo) como bast geral do estudo da evolução das espécies na Terra, acompanhando a evoluçào do ambiente, influcnciada por este mas irlluenciando-o tamhém de forma decisiva. pelo que se podcrá dizer qué a cvoluçảo da vida c do nosso plancta é conjunta e inseparável.

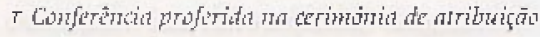 du próuna Ferreira da Silla - 2000

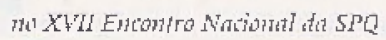

- Canrm de Qumian Estrutara! - T.S.T.

\section{BIBLIOGRAFIA}

Ms bases essenciais da nossa exposiçăo encontrant-se descritas enr profundidade nos saguinles tras volumes a arligo de revisāo:

1. I.J.R. Fraústo da Siva and R.J.P. Willianas (1991. 2aㅡ reimpressajo]997). The biological chemistry of the elements - the inorganic chemisty of fife. Oxford Universily Press. Oxford

2. R.J.P. Williams and J.J.R. Fraústo da Silva 11996, reimpresso1947). The biological sevection or the chenicat elements - the onvromment and life s chemistry. Oxlord Univer sity Press. Oxtord

3. R.I.P. Williams and J.J.R. Frausto da Silka (1999). Bringing chemisty to life - from matter to man. Oxiord Universily Press. Oxford

4. R.I.P. Witliams and I.J.R. Frausto da Silva (2000). The dislpibution of elements in cells.

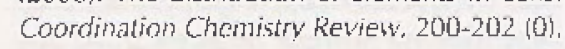
$247-348$. 